\title{
THE INFLUENCE OF MANAGERIAL OWNERSHIP, EARNINGS MANAGEMENT, INTELLECTUAL CAPITAL, AND TAX AGGRESSIVENESS TO FIRM VALUE
}

\author{
Mutia Zahra, Rosita Wulandari, Syafrizal \\ Pamulang University \\ Email: mutiaumi51@gmail.com
}

\section{ARTICLE INFO}

Article History:

Received 22 May 2018

Revised 15 June 2018

Accepted 15 July 2018

JEL Calssification:

G32, G34, H26, M41

\section{Keywords:}

Managerial Ownership, Earnings Management, Intellectual Capital, Tax Aggressiveness, and Firm Value

\begin{abstract}
This study aims to examine the factors that affect the value of the company. The independent variable used is managerial ownership, profit management, intellectual capital and aggressive tax action. This research method uses secondary data types. The sample of this research is manufacturing company of industrial sector of consumer goods listed in the Indonesia Stock Exchange. The sample was chosen by purposive sampling. The number of companies taken as the sample is 10 companies within 2011-2015 period. To test the hypothesis, this study uses a significant level of 0,05 . It shows that managerial ownership, management and aggressive tax earnings measurements have no significant effect on firm value, while intellectual capital has a positive and significant influence on firm value.
\end{abstract}

\section{INTRODUCTION}

The general objective of every company whether the company went public and companies not to go public is to increase the value of the company. Achievement of a high value of the company is intended to maximize shareholder wealth levels. Achievement of these two things will ultimately, attract shareholders to invest their funds in the company (Brigham Gapensi, 1996). In running a business, as the principal shareholder delegated management of the company to the manager as the agent in the hope that the managers acting on behalf of the owners to achieve its goals. But in reality, the managers tend to act for the sake of personal gain and that is what led to the involvement of the agency conflict (Jansen dan Meckling (1976). Increased managerial ownership helps to connect the internal party interests and shareholders, and lead to better decision making and increased value of the company. Thus, the company's activities can be monitored through a great managerial ownership (Endraswati, 2012). The purpose of the financial management of a company is to maximize the value of the company. The value of the company itself is "willing to pay the price that potential buyers if the company is sold" (Husnan and Pudjiastuti, 2006). Maximizing the value of the company will be equal to maximize the well-being that will be accepted by stakeholders. Then, when the maximum or higher a company's value, the greater the prosperity that would be acceptable stakeholders. The value of the company became a benchmark for investors to assess the company's performance.

Profit is one of the performance parameters of companies that get major attention from investors and creditors because they use the profit to evaluate company's management. Earnings quality is based on a qualitative concept from Conceptual Framework (FASB, 1978) Earnings quality is the profit that is useful in decision 
Mutia Zahra: The Influence of Managerial...

making that has the characteristics of relevance, reliability and comparability / consistency.

If the company has profits every year, then the company will think whether the profits obtained will be given all or partially or entirely retained to be reinvested. Information asymmetry between managers and shareholders provides flexibility for management to freely determine the accounting methods and estimates used in reporting company profits so as to provide opportunities for management to conduct earnings management (Indriani, 2014). Earnings management constitute interference in the management of the process of preparing the company's financial statements for external parties in order to reach a certain income level with the aim to benefit himself or his own company that increases the value of the company (Setiawati, 2000).

Earnings management rated as a manager managed to mislead others in assessing the company's management. This understanding is consistent with agency theory that suggests that the separation of ownership and management of the company will encourage managers attempt to maximize welfare, although they had to trick the other party (Sulistyo, 2008).

Human capital or more precisely called intellectual capital also needs to be sustained by knowledge assets that will later enable them to increase the value of the company into something more valuable. These knowledge assets include: talents, skills, technology know-how and know-what, equipment artifacts, and machines related to the value added process (Zuhal, 2010)

Tax is one of the main income sources of a country in order to finance the government organization for the provision of public goods and services as well as construction.

But for businesses and investors, the tax burden would still be considered an investment. Therefore, it is reasonable if the employers are trying to avoid the tax burden with effective tax planning. Arnold and McIntyre, 1995 mentions that the tax evasion (tax avoidance) is an attempt evasion or tax savings within the framework of fulfilling legislative provisions (lawful fashion). Tax avoidance, must be distinguished from tax evasion (tax smuggling) generally is against the law (illegal) and includes acts intentionally did not report complete and correct way to tax or legal violation (fraud) others. Although legal can be distinguished, economically both tax planning through tax avoidance and tax evasion together result in reduced tax revenues. Arrangements for transactions that have the potential to minimize the tax burden to obtain tax savings are tax planning.

\section{LITERATURE REVIEW}

\section{Signaling Theory}

Signaling theory is an action taken by the management of a company that gives guidance to investors about how management consider the company's prospects (Brigham and Houston, 2001).

According to (Jama'an, 2008) Signaling Theory argued about how should a company give a signal to users of financial statements. These signals in the form of information about what has been done by the management to realize the wishes of the owner. Signals can be either promotional or other information which states that the company is better than any other company. Signal theory explains that the signaling is done by managers to reduce information asymmetry. Managers provide information through the financial statements that they are applying the accounting policies of conservatism that produces higher quality earnings for this principle prevents companies taking action to exaggerate profits and helps users of financial statements to 
present the earnings and assets not overstate.

\section{Agency Theory}

Agency theory is a relationship based on a contract that occur between members of the company, ie, between the principal (owner) and agent (agent) as the main actors (Jensen \& Meckling: 1976). The owner is the party that gives a mandate to the agent to act on behalf of the owner, while the agent is a party that is mandated by the owners to run the company. Agency relationship arises when one or more principal employs an agent to provide a service and then delegate decision-making authority to the agent.

\section{Managerial ownership}

Managerial ownership is ownership of shares owned by management company. This level of managerial ownership is measured by dividing the number of shares owned by the controlling shareholder by the number of shares outstanding (Hardiningsih, 2009). Every company has a goal to create value for its owner (shareholder) by maximizing the wealth of the owner (Gitman, 2006). In achieving these objectives, owners often have limitations in the management of the company. This triggers the owner to assign responsibility for managing the company to a second party called the manager.

\section{Profit management}

Earnings management performed by the management of an enterprise by utilizing the items accrued in the financial statements, namely by using discretionary accruals. Accruals discretionary are used to reduce or enlarge the reported earnings by selecting accounting policies by management that are subjective (Armando, 2012). Earnings management is manager attempts to influence the information in the financial statements with the intention to deceive stakeholders who want to know the performance and condition of the company (Sulistyanto, 2008).

\section{Intellectual capital}

Intellectual capital is defined as information and knowledge are applied in the work to create value (Williams, 2001). Investors will give a higher value to the company that has the intellectual resources are higher than those companies that have a low intellectual. The value assigned by investors to the company will be reflected in the stock price of the company (Chen et al, 2005). Based on some opinions on the above it can be concluded that the intellectual capital (intellectual capital) is more value itself can be derived from the ability to produce a company and as a combination of resources for intangible and activities that allow organizations menstransformasi a bundle of material, financial and human resources in a skill system for creating stakeholder value.

\section{Aggressive Tax Measures}

Aggressive tax is an act which aims to reduce taxable income through tax planning using either the way classified or not classified as tax evasion. Although not all acts carried out inviolation of the rules, but the more loopholes used by the company then the company is considered to be more aggressive (Frank et al, 2009).

\section{The value of the company}

The company value, which is the value of the Company are certain conditions that have been achieved by a company as an overview of public confidence in the company for several years since the company was founded until now. Measurement Value This company uses PBV (price to book value) is the market price of the stock divided by the price of the book value per share (Brigham and Houston, 2006). 


\section{Framework for Thinking}

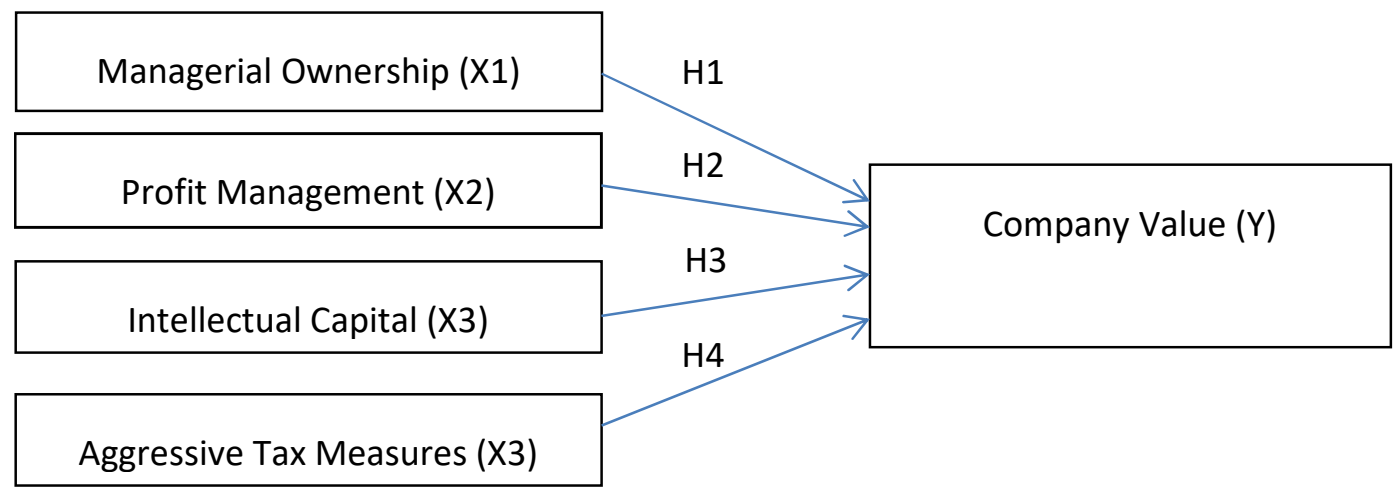

Figure.1 Framework of thinking

\section{DATA AND RESEARCH TECHNIQUE ANALISYS}

The type of data in this research are secondary data from the financial statements of companies manufacturing consumer goods industries listed in Indonesia Stock Exchange for the period 2011-2015. Data source company financial statements have been audited in 2011-2015 was obtained from www.idx.co.id.

The sampling technique used in this research is purposive sampling. Purposive sampling is a sampling technique with a certain consideration (Sugiono, 2013). The samples studied by researchers is 10 (ten) Consumer Goods Industry Company listed on the Stock Exchange with an annual financial report 2011-2015.

The independent variable in this study is the Managerial Ownership (X1), Profit Management (X2), Intellectual Capital (X3), Aggressive Tax Measures (X4). Scale or size used in this study is the ratio. The size ratio is a measure that includes all sizes that give information about the absolute value of the measured object (Moh. Nazir, 2009). In the scale ratio of the number zero has a meaning, so that the number zero on this scale is needed as a basis for the calculation and measurement of the object under study.

\section{Managerial ownership}

The first independent variable in this study is the Managerial Ownership, Managerial ownership is the level of ownership by the management who are actively involved in decision making.

The measurement is seen from the large proportion of shares owned by management at the end of the year is presented in percentage (Yadnyana and Wati 2011 in Riza Bernandhi, 2013).

$M N G R$

$=\frac{\text { Jumlah saham y dimiliki Komisaris }+ \text { Direktur }}{\text { Total keseluruhan Saham Perusahaan }} \times 100 \%$

(1)

\section{Profit management}

Profit Management is the effort of company managers to influence information in financial statements with the aim of tricking stakeholders who want to know the performance and conditions of the company (Sulistyanto, 2008), which is measured by calculating Total Accruals with cash flow and income statement approaches calculated using the De model formula Angelo where this model calculates total accruals (TAC) as the difference between accounting earnings obtained by a company for one period with the cash flow of the period concerned or formulated as follows: 
TAC $=$ Net income - Cash flow operations (2) Net income is the difference between income over expenses and is a net increase in working capital originating from business activities during a certain period. Cash flow operation is cash arising from the company's operational activities related to revenues, expenses, income, and costs. This cash illustrates how companies can profit and convert into cash. De Angelo's model measures or proxies earnings management with non-discretionary accruals, which are calculated using the total period-end accruals scaled by the total assets of the previous period. Or formulated as follows:

$$
\mathrm{NDA}_{\mathrm{t}}=\mathrm{TAC}_{\mathrm{t}-1}(3)
$$

Information:

NDAt = Discretionary accruals that in the estimation

Tact $=$ Total Accrual period $\mathrm{t}$

TAT $-1=$ Total Assets period $\mathrm{t}-1$

\section{Intellectual Capital}

Intellectual capital is a form of knowledge resources such as customers, employees and technology competence which companies can use it in the process of value creation (Uluum, 2009). Intellectual capital performance as measured by the value added created by physical capital, human capital and structural capital. VAICTM is a combination of three indicators of value added which can be expressed as follows:

$$
\text { VAICTM = VACA + VAHU + STVA (4) }
$$

\section{RESULT AND DISCUSSION}

Classic assumption test

Normality test

Table 1. Kolmogorov-Smirnov test results

\begin{tabular}{l|l|r}
\hline \multicolumn{3}{c}{ One-Sample Kolmogorov-Smirnov Test } \\
\hline $\mathrm{N}$ & \multicolumn{1}{|c}{ Residual unstandardized } \\
\hline \multirow{2}{*}{ Normal Parametersa, b } & mean & .0000000 \\
\cline { 2 - 3 } & Std. deviation & .43029084 \\
\hline \multirow{2}{*}{ Most Extreme Differences } & Absolute & .103 \\
\cline { 2 - 3 } & positive & .103 \\
\cline { 2 - 3 } & negative &. .089 \\
\hline Test Statistic & .103 \\
\hline Asymp. Sig. (2-tailed) & $.200 \mathrm{c}, \mathrm{d}$ \\
\hline a. Test distribution is Normal. & \\
\hline b. Calculated from data. & \\
\hline \multicolumn{2}{l}{ c. Significance Lilliefors Correction. } \\
\hline d. This is a lower bound of the true significance. \\
\hline
\end{tabular}

Source: SPSS 22

One-sample test results of the Kolmogorov-Smirnov in Table 1 above shows the significance level of 0.200 . Because the value of $\mathrm{P}$ (Asymp.Sig.) Is greater than the level 0.05 , it can be concluded that the data residuals in this regression model are normally distributed. 
Mutia Zahra: The Influence of Managerial...

\section{Multicollinearity Test}

Table 2. Multicollinearity test result

\begin{tabular}{|c|c|c|c|c|c|c|c|c|}
\hline \multicolumn{9}{|c|}{ Coefficientsa } \\
\hline & & \multicolumn{2}{|c|}{$\begin{array}{c}\text { Coefficients } \\
\text { unstandardized }\end{array}$} & $\begin{array}{l}\text { standardized } \\
\text { Coefficients }\end{array}$ & \multirow[b]{2}{*}{$\mathrm{t}$} & \multirow[b]{2}{*}{ Sig. } & \multicolumn{2}{|c|}{ collinearity Statistics } \\
\hline \multicolumn{2}{|c|}{ Model } & $\mathrm{B}$ & Std. Error & beta & & & tolerance & VIF \\
\hline \multirow[t]{5}{*}{1} & (Constant) & 1391 & .886 & & 1,571 & .123 & & \\
\hline & mngr & -.426 & .399 & -.134 & -1066 & .292 & .889 & 1,125 \\
\hline & MNJL & $-2.748 \mathrm{E}-7$ & .000 & -.298 & -1816 & .076 & .525 & 1,906 \\
\hline & VAIC & .909 & .264 & .578 & 3,437 & .001 & .501 & 1,998 \\
\hline & ETR & -2362 & 1,272 & -.243 & -1857 & .070 & .829 & 1,207 \\
\hline
\end{tabular}

a. Dependent Variable: PBV

Source: SPSS 22

It can be seen from VIF (variance of 1 to 10 . It can be concluded that there was inflation factor) all of the variables is the range no trouble multicolinierity.

\section{Autocorrelation test}

Table 3. Autocorrelation test result

\begin{tabular}{l|c|r|r|r|r}
\hline \multicolumn{1}{c|}{ Model Summary } \\
\hline Model & $\mathrm{R}$ & R Square & $\begin{array}{c}\text { Adjusted R } \\
\text { Square }\end{array}$ & $\begin{array}{c}\text { Std. Error of the } \\
\text { Estimate }\end{array}$ & Durbin-Watson \\
\hline 1 & $.603 a$ & .364 & .307 & .449008 & 1,122 \\
\hline
\end{tabular}

a. Predictors: (Constant), ETR, MNJL, mngr, VAIC

b. Dependent Variable: PBV

Source: SPSS 22

Under the Durbin-Watson test results in test indicates the value of 1,122 , where the figure is between -2 to +2 . it can be concluded Table 3. The above can be seen that the test autokolerasi on the value of the Durbin-Watson that there is no autocorrelation in the research data

\section{Heteroscedasticity test}

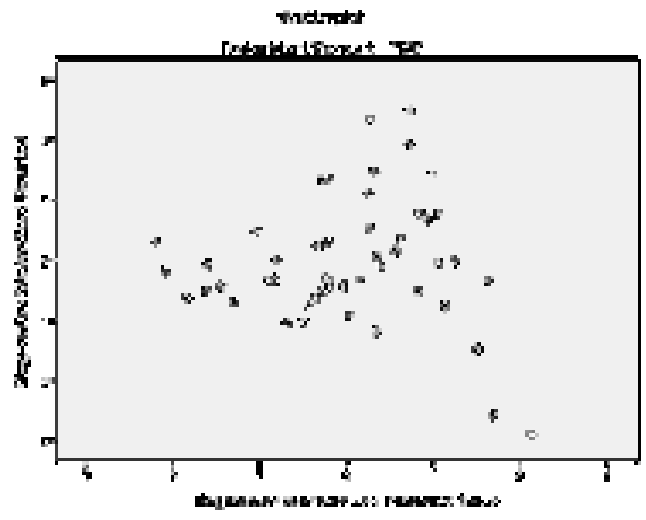


Source: SPSS 22

Figure 2. Test Results Heteroskidastity

Heteroskedastisity test results of shows the pattern of deployment, which saw that the points spread above and below 0 on the axis
$\mathrm{Y}$. This indicates that there is no heteroscedasticity in the data use

\section{Multiple Linear Regression Analysis}

Table 4. Results of Multiple Linear Regression Analysis

\begin{tabular}{|c|c|c|c|c|c|c|}
\hline \multicolumn{7}{|c|}{ Coefficientsa } \\
\hline & & \multicolumn{2}{|c|}{ Coefficients unstandardized } & $\begin{array}{l}\text { standardized } \\
\text { Coefficients }\end{array}$ & \multirow[b]{2}{*}{$\mathrm{t}$} & \multirow[b]{2}{*}{ Sig. } \\
\hline \multicolumn{2}{|c|}{ Model } & $\mathrm{B}$ & Std. Error & beta & & \\
\hline \multirow[t]{5}{*}{1} & (Constant) & 1391 & .886 & & 1,571 & .123 \\
\hline & mngr & -.426 & .399 & -.134 & -1066 & .292 \\
\hline & MNJL & $-2.748 \mathrm{E}-7$ & .000 & -.298 & -1816 & .076 \\
\hline & VAIC & .909 & .264 & .578 & 3,437 & .001 \\
\hline & ETR & -2362 & 1,272 & -.243 & -1857 & .070 \\
\hline
\end{tabular}

a. Dependent Variable: PBV

Source: SPSS 22

Table 4 can be formulated based on the regression equation as follows:

$P B V=1.391-0,426 \mathrm{MNGR}-2,748 \mathrm{E}-7 \mathrm{MNJL}+$ 0,909 VAIC $-2,362 \mathrm{ETR}+0.886$

From the above results it can be seen that managerial ownership (MNGR), Earnings Management (MNJL) and Aggressive Tax Action (ETR) have a negative towards the value of the Company. While Intellectual Capital (VAIC) has a positive towards the value of the Company.

Test Results The coefficient of Determination $\left(R^{2}\right)$

Table 5 : Coefficient Determination Test Results

\begin{tabular}{l|c|c|c|c}
\hline \multicolumn{5}{c}{ Model Summaryb } \\
\hline Model & $\mathrm{R}$ & R Square & $\begin{array}{c}\text { Adjusted R } \\
\text { Square }\end{array}$ & $\begin{array}{c}\text { Std. Error of the } \\
\text { Estimate }\end{array}$ \\
\hline 1 & $.603 a$ & .364 & .307 & .44901 \\
\hline \multicolumn{5}{l}{. Predictors: (Constant), ETR, MNJL, mngr, VAICTM } \\
\hline \multicolumn{5}{l}{ b. Dependent Variable: PBV } \\
\multicolumn{5}{l}{ Source: SPSS 22}
\end{tabular}

In Table 5 shows the value of the determinant coefficient R2 of 0.307 or $30.7 \%$. This means that $30.7 \%$ Corporate Value variable can be explained by the variable Managerial
Ownership, Profit Management, Intellectual Capital and Aggressive Tax. While the remaining amount $(100 \%-30.7 \%=69.3 \%)$ is explained by other factors that are not included in the regression analysis in this study.

\section{Simultaneous testing}


Mutia Zahra: The Influence of Managerial...

Table 6. Simultaneous Test Results (Test F)

\begin{tabular}{|c|c|c|c|c|c|c|}
\hline \multicolumn{7}{|c|}{ ANOVAa } \\
\hline \multicolumn{2}{|c|}{ Model } & $\begin{array}{l}\text { Sum of } \\
\text { Squares }\end{array}$ & df & mean Square & $\mathrm{F}$ & Sig. \\
\hline \multirow[t]{3}{*}{1} & Regression & 5190 & 4 & 1,297 & 6436 & $.000 \mathrm{~b}$ \\
\hline & residual & 9,072 & 45 & .202 & & \\
\hline & Total & 14262 & 49 & & & \\
\hline
\end{tabular}

a. Dependent Variable: PBV b. Predictors: (Constant), ETR, MNJL, mngr, b.Predictors: (Constant), ETR, MNJL, mngr, VAICTM

Source: SPSS 22

Based on Table 6 shows that the statistical test $F$ have calculated $F$ value of $6.436>2.58$ with a significance value of 0.000

level of significance is much smaller than the value of 0.05 or $0.000<0.05, F_{\text {tabel }}$ this it can be concluded that the regression model in this study can be used.

\section{Partial testing}

Table 7. Partial Test Results (t test)

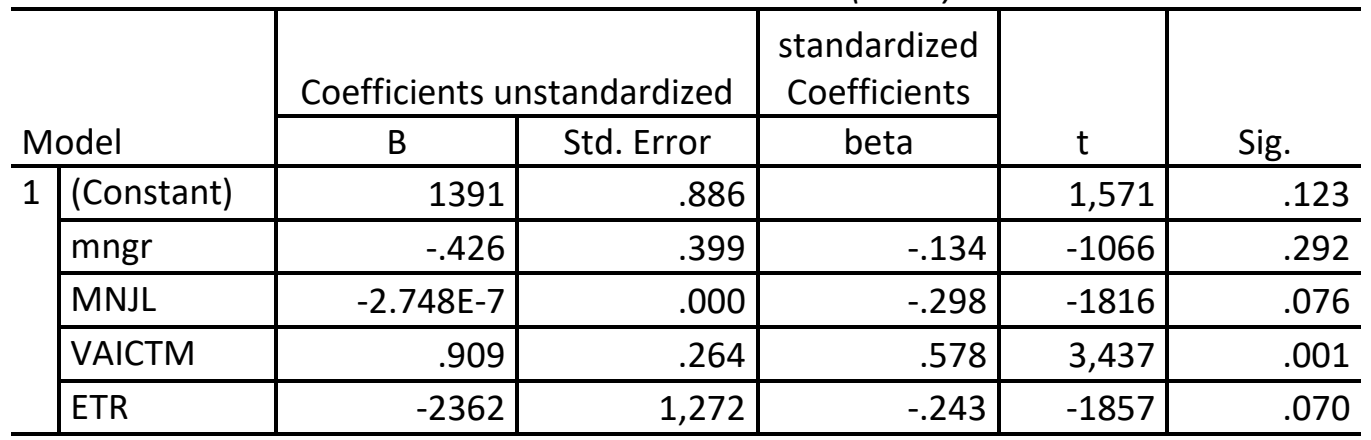

a. Dependent Variable: PBV

Source: SPSS 22

1) Effect of Earnings Management of the Company Value

Hypothesis $1(\mathrm{H} 1)$ in this study was to examine whether Managerial Ownership affect the value of the Company. Results of regression showed $t$ values of 1.066 and a significance level of $0.292>0.05$ and negative $t$ value indicates that the Managerial Ownership has the opposite relationship to the value of the Company. It can be concluded that the hypothesis 1 is rejected, Ho accepted. This is because the ownership of the company Managerial Consumer Goods Industry in Indonesia tends to be very low, it can be seen from its descriptive statistical averaging only managerial ownership amounted to 0.1320 .

This study is in line with research Mohd Hassan Che Haat (2008) who found that managerial ownership does not affect the value of the company.

\section{2) Effect of Earnings Management of the Company Value}

Hypothesis $2(\mathrm{H} 2)$ in this study was to test whether the effect on the Value Profit Management Company. Results of regression showed $t$ values of 1.816 and a significance level of $0.076>0.05$. It can be concluded that the second hypothesis is rejected, Ho accepted. earnings management actions undertaken by managers will have no impact on the value of the company.

This is consistent with previous studies conducted by herman Dervish (2012), Megawati (2009), which indicates that earnings management does not affect the value of the 
company.

\section{3) Effect of Intellectual Capital on Firm Value}

Hypothesis $3(\mathrm{H} 3)$ in this study was to test whether the effect on the value of Intellectual Capital Company. Results of regression showed $t$ values of 3.347 and a significance level of $0.001<0.05$. From these results suggest that 3 hypothesis is accepted, Ho rejected. If intellectual capital increase, in the sense of well-managed, then this will increase market perceptions of the value of the company. Companies that manage their intellectual resources to the maximum to be able to create greater added value and competitive advantage, which will lead to an increase in the value of the company.

The results are consistent with research, Chen et al (2005).

\section{4) Influence of Aggressive Tax Measures on Corporate Values}

Hypothesis $4(\mathrm{H} 4)$ in this study was to examine whether action Aggressive Tax effect on the value of the Company. Results of regression showed $t$ values of 1.857 and $a$ significance level of $0.070>0.05$. From these results indicate that the hypothesis 4 is rejected, Ho accepted. Losses incurred namely the possibility of the company to get sanctions / penalties from the tax authorities of tax, and the drop in stock price.

This study are consistent with previous studies Dhini Khatulistiyani (2016) and Nike Beliza (2015).

\section{CONCLUSION}

Managerial Ownership variables did not significantly affect the value of the company. It can be concluded that $\mathrm{H}_{1}$ rejected.

Profit Management variables did not significantly affect the Company Values. It can be concluded that the $\mathrm{H} 2$ is rejected.

Intellectual Capital Variable significant positive effect on company value. From these results suggest that the $\mathrm{H} 3$ is accepted.
Variable Aggressive tax measures do not affect the value of the Company. From these results indicate that the $\mathrm{H} 4$ is rejected.

\section{REFERENCES}

Abidin. Q. (2000). The difficulty of Intellectual Capital. Media Accounting, October, pp 45-48.

Beliza, N. (2015). Effect of Tax Aggressiveness, Level Earnings Persistence, and Corvorate Governance on Firm Value.

Bernandhi, Riza. 2013. Effect of Managerial Ownership, Institutional Ownership, Dividend Policy, Leverage, and company size.

Brigham, Eugene F and Gapenski, Louis C. (1993). "International Financial Management", The Dryden Press, Florida

Chen, MC, SJ Cheng and Y. Hwang. (2005). An Empirical Investigation of The Relationship Between Intellectual Capital and Firms Market Value and Financial Performance. Journal of Intellectual Capital, 6 (2), pp 159-176.

Dewi, Tamia. (2016). Influence of the Value Profit Management Company with Quality Audit as moderating variables. Vol. 3, No. December 3, 2016 pp 3401.

Fauzi, A. 2016. Effect of Taxes on Value Aggressiveness Company with Variable Information Transparency as Moderation (On Mining Companies listed on the Stock Exchange from 2012 to 2014).

Frank, M. et al. (2009). Tax Reporting aggressiveness and Its Relations to Aggressive Financial Reporting. The Acounting Review, 84, pp 467-496.

Ghozali, I. (2016). Multivariate Analysis Applications with IBM Program SPSS23. Semarang: Undip.

Gunadi. (2007). International Tax. Jakarta: Faculty of Economics, University of Indonesia. -. (2009). Tax Accounting. Jakarta: Grasindo. 
Hand, D. 2015. Effect of Earnings Management and Intellectual Capital on Firm Value. Essay

Indriani Poppy, et al., JOURNAL OF Accounting \& Finance Vol. 5, No. 1, March 2014 Pages 19-32, Bina Darma University.

Setiawati, Lilis. (2000). Manajemen Laba. Journal of Indonesian Economics and Business, Vol. 15, No. 4, pp 424-441.

Sri, S. (2008). Profit Management (Theory and Empirical). Jakarta: Garasindo.

Sugiyono. (2013). Education Research Methods in Quantitative Approach, Qualitative and $R$ \& D. Bandung: Alfabeta.

Ulum, I. (2009). Intellectual Capital: Concept and Empirical Study. Yogyakarta: Graha Science.

Law No. 28 Year 2007 on General Provisions and Tax Procedures (UUKUP).

Williams, S,M. (2001). Is Intellectual Capital Performance and Disclosure Practice Related? Journal of Intellectual Capital Vol 2, No. 3.

www.idx.co.id (Accessed on June 8, 2017)

Yuniasih, NW, et al. (2010). Exploration Company Performance: Study Pursuant Intellectual Capital. National Symposium Accounting Purwokerto. 